\title{
Utilising E-Learning to Assist Primary School ESL Pupils in Learning to Spell during COVID-19 Pandemic: A Literature Review
}

\author{
Emily Lau Yen Yen, Maslawati Mohamad* \\ Faculty of Education, Universiti Kebangsaan Malaysia, Bangi, Malaysia \\ Email: elyy@edidik.edu.my, *maslawati@ukm.edu.my
}

How to cite this paper: Yen, E. L. Y., \& Mohamad, M. (2020). Utilising E-Learning to Assist Primary School ESL Pupils in Learning to Spell during COVID-19 Pandemic: A Literature Review. Creative Education, 11, 1223-1230.

https://doi.org/10.4236/ce.2020.118091

Received: July 10, 2020

Accepted: August 7, 2020

Published: August 10, 2020

Copyright (c) 2020 by author(s) and Scientific Research Publishing Inc. This work is licensed under the Creative Commons Attribution-NonCommercial International License (CC BY-NC 4.0).

http://creativecommons.org/licenses/by-nc/4.0/

\begin{abstract}
Learning to spell is important in English Language learning. However, primary school ESL pupils struggled with it. Various factors influence the pupils' difficulties in spelling. In order to improve their ability in learning to spell, a new approach should be employed, parallel to Information and Communication Technology (ICT) in the $21^{\text {st }}$ century learning. The unprecedented COVID-19 pandemic created a new norm in the society in which one of the affected sectors is education. Following, e-learning becomes a necessity to transcend knowledge. This paper imparts a literature review on the 1) challenges faced by the primary school ESL pupils in learning to spell and 2) measures to overcome the challenges faced by the primary school ESL pupils in learning to spell via e-learning during COVID-19 pandemic.
\end{abstract}

\section{Keywords}

Learning to Spell, Primary School ESL Pupils, $21^{\text {st }}$ Century Learning, COVID-19 Pandemic, E-Learning

\section{Introduction}

English language is notably the global lingua franca as highlighted by Peter et al. (2013). In Malaysia, it is regarded as the second language and a compulsory subject in the educational institutions as explicated by Thirusanku and Yunus (2014).

Following, the Ministry of Education Malaysia (2018) highlighted that the current Primary School Standard Curriculum (KSSR) implemented for the English subject syllabuses for Year One till Year Four are aligned to the Common European Framework of References (CEFR). It stated that the Year Five and Year Six syllabuses for the English subject will also gradually be aligned to the 
CEFR. The basic English language skills will be provided so that pupils can communicate well in the language (Ministry of Education Malaysia, 2018).

Parallel to this, Treiman et al. (2019) asserted that it is essential to write syntactically correct sentences with accurate spelling as the 21st-century teaching and learning majorly involves communication via writing. They believed that primary school pupils should have a decent grasp of the English word spelling. Nevertheless, the pupils faced challenges in learning to spell due to the pupils' mother tongue interference, limitations in spelling skill, ignorance and confusion with the language orthography.

However, the unprecedented COVID-19 crisis has caused the face-to-face classrooms to be no longer permitted by many countries as a measure to curb the spread of COVID-19 pandemic (Rahman, 2020). As such, e-learning is widely practiced around the globe despite ambivalent feelings by some educators (Kamenetz, 2020). She added that it resulted in a survival condition, emerging as the "new normal". This trains the primary school ESL pupils to develop independent-learning ability in their quest to improve in their learning to spell amid the COVID-19 pandemic. Mohamad et al. (2020) supported the concept of 21st-century learning which utilizes Information and Communication Technology (ICT) to augment the perceptions of the generation $\mathrm{Z}$ pupils. This is consonant with the 7th shift of the Malaysia Education Blueprint (MEB) 2013-2025 which is to elevate ICT to leverage effective learning across Malaysia.

The researcher realised the importance of learning to spell in language learning yet the primary school ESL pupils faced the challenges in learning to spell. The purpose of this literature review is to identify the measures to overcome the challenges faced by the primary school ESL pupils in learning to spell through e-learning during COVID-19 pandemic. The following research questions will be answered in this literature review:

1) What are the challenges faced by the primary school ESL pupils in learning to spell?

2) What are the measures to overcome the challenges faced by the primary school ESL pupils in learning to spell via e-learning during COVID-19 pandemic?

\section{Literature Review}

\subsection{The Challenges Faced by the Primary School ESL Pupils in Learning to Spell}

Spelling is fundamental to the learning of English as a second language. According to Cook (1999), as cited in Ahmed (2017), pupils failed to identify the four main types of spelling errors namely substitution (to replace letters with incorrect ones), omission (to leave letters out), insertion or addition (to include extra letters) and transposition (to reverse the position of letters). This leads to the challenges faced by the primary school ESL pupils in learning to spell precisely.

In the Malaysian context, the spelling of words is adopted according to the British English variety (Amin, 2012). There are many varieties of the English language for example, the word "color" (American English) or "colour" (British 
English). Hence, the pupils should be aware of the existence of these spelling varieties and its applicability based on its context.

The short messaging system (SMS) "texting" language inhibited the primary school ESL pupils in learning to spell as agreed by Verheijen (2013). They are directly exposed to this "texting" language through their communication in social media such as in Whatsapp, Telegram, Facebook etcetera. It appeared that pupils are adapted to use abbreviation of words to represent the meaning for the complete words. For example, words like "Please" as "Pls", "Thank you" as "Tq" and "Welcome" as "Wc". Nevertheless, "texting" language is only acceptable in informal communication while having to spell the words in their precise full forms in formal language learning and writing (Verheijen, 2013). However, she was concerned that this may result in pupils' long-term difficulty in learning to spell the English words correctly.

Evidently, standardised spelling facilitates clarity in writing. Westwood (2014) commented that misspelt words might influence and affect pupils' written work consequentially. It has been discovered that pupils with low spelling confidence and skills usually write lesser and with reduced authority compared to the confident spellers (Ahmed, 2017; Dheifallah \& Radzuwan, 2019).

Another prominent challenge is the pupils' confusion in the spelling of words. It can destabilize memory of the right word types and deterioration in the pupils' spelling capacity. The pupils' confusion is also influenced by the inconsistency in the English language orthography which may have been copied from other languages such as Latin, French and Greek. In fact, the original form of certain words is sometimes retained in English for example, "fiancée" and "clichés".

Bakar et al. (2018) revealed in her research that the Malaysian primary school ESL pupils have been struggling in mastering the language due to inattention and limited spelling skills. She added that English spelling can be tricky to the pupils because many words sound similar (homophones) but are different in their spelling and meanings. For instance, the words "tale" (story) and "tail" (the hindmost part of an animal) exhibited different meanings yet with the same pronunciation. As Westwood (2014) put it earlier, English is not a bilateral sound to letter or sound to sound correspondence.

Besides, the primary school ESL pupils faced mother tongue interference as part of their challenges in learning to spell. Samuddin \& Krish (2018) discovered in their findings that a major concern in L2 (English) spelling among the Malay primary school pupils is the opaque orthography of the English language which vastly differs from their L1 (Bahasa Malaysia). In the research done by Yeung and Qiao (2019), Chinese ESL pupils also suffered spelling difficulties the most compared to other cognitive-linguistic skills.

Clearly, in the context of the Malaysian primary school ESL pupils, a good grasp of spelling which is the stepping stone of acquiring other language skills is unquestionable. An interesting aspect is that even among spellers who are proficient, certain words will have full and accurate spelling that is stored in memory (high-quality), whereas other words have inaccurate representations (Perveen \& 
Akram, 2014). Therefore, the teachers need to resolve the learning challenges by assisting the primary school ESL pupils through generating schema and linking them.

\subsection{E-Learning for Learning to Spell}

Generally, both e-learning and distance learning are mutually reciprocal, particularly for language learning. This type of learning is known as Technology Enhanced Language Learning (TELL) whereby Hashim (2018) referred as the language learning process via a technology-based platform as in the $21^{\text {st }}$ century learning. Ahmadi (2018) added that e-learning provided opportunities for pupils to complete computer tasks rather than regular pencil and paperwork. Learning can still continue even though the physical participation by the teacher and pupils are not possible due to the unprecedented COVID-19 pandemic.

By engaging themselves with e-learning, Mohamad et al. (2018) expressed that learners will be exposed to a productive language environment whereby they can interact and learn simultaneously with other users. As such, teachers who use Education 4.0 tools routinely need to consider new digital literacy of e-learning to ensure learners can engage in a meaningful practice (Chartrand, 2011). This is due to the versatility of e-learning in improving pupils in their learning to spell instead of through the conventional rote memorisation method (Menelaos \& Chris, 2011). Besides, the research conducted by Bakar et al. (2018) revealed that the primary school pupils were successful in their learning to spell through e-learning using Telegram Autobot. It is a messaging application; allowing pupils to visualise the words in their mind before they spell them correctly.

The abundant literature discussed may make it look like learning to spell is an issue that has been getting considerable attention but in reality, minimal focus has been given to the field of spelling. Nonetheless, the genuine connection between digital and teaching methodology is crucial to attract pupils' attention in learning to spell (Ahmadi, 2018).

\subsection{The Measures to Overcome the Challenges Faced by the Primary School ESL Pupils in Learning to Spell via E-Learning during COVID-19 Pandemic}

Interestingly, in view on the perspective of English as a second language, Krashen (1985) argued that people could attain a second language if they comprehend and have a low affective filter to allow "in" the input. Similarly, with the use of e-learning, the primary school ESL pupils can interact in cyberspace freely and safely without feeling inferior of making mistakes in learning to spell thus creating a low filter learning environment.

Botley et al. (2007) discovered the orthographic errors in argumentative essays by university students using CALES (Sabah/Sarawak Corpus Database of Pupils English) whereby it has reduced the spelling errors among them. Likewise, Qing et al. (2007) highlighted that error rate reduction in comparison with the computer-based teaching methods made use of their ability to incorporate different 
input modalities and therefore are useful tools in teaching spelling.

Next, Yunus et al. (2013) and Yunus et al. (2014) discovered in separate researches that the substitution of social networking services as e-learning platforms for integration in an ESL classroom assisted in increasing pupils' knowledge and motivation in English language learning. The past studies also revealed how e-learning has been utilized to assist primary school ESL pupils in learning to spell through mobile phones, laptops, computers and accessibility of Internet connection in or beyond the classroom.

Correspondingly, a research survey by Sumreet \& Charanjiv (2014) regarding ICT-based software which is a spellchecker is able to analyse possible misspellings in the text and provide suggestions for the incorrectly spelt words. Rana et al. (2016) supported that learning to spell will probably be successful if it is based on the previous experience of the pupil which helped promote active learning.

Additionally, Bakar et al. (2018) observed on how telegram which is used as an e-learning tool platform can improve the primary school ESL pupils in learning to spell on compound nouns. The qualitative data collected from the observation checklists, interviews and document analysis illustrated positive feedbacks after the intervention concerning the use of quizzes in the telegram.

Besides, the advanced education pioneers can leverage IR 4.0 potential by offering their foundations in the computerized administration. This is crucial particularly during the COVID-19 pandemic as the online learning to spell is the mainstream education in a new normal condition (Shahroom \& Hussin, 2018).

The findings from Yunus et al. (2020) supported the advantages brought by utilising ICT in language lessons. Moreover, by adopting an e-learning platform, Rafiq et al. (2020) believed that the goal of educators is to move from making pupils understand that they must learn to quench their thirst for knowledge.

\section{Conclusion and Implications}

This paper provided a literature review on the challenges faced by the primary school ESL pupils in learning to spell and the measures to overcome them via e-learning during the COVID-19 pandemic. Among the inhibiting factors faced by primary school ESL pupils were due to their limited spelling skill, mother tongue interference, confusion in the spelling of words and etcetera. The measures to overcome the challenges faced by primary school ESL pupils in learning to spell via e-learning during COVID-19 pandemic were based on multiple research findings to support their claims.

This literature review on the use of e-learning to improve primary school ESL pupils on learning to spell during COVID-19 pandemic gives some implications to the ESL pupils, teachers and parents. The implication of e-learning towards the primary school ESL pupils revealed that it could increase pupils' motivation and ensures meaningful knowledge in learning to spell at their own pace.

E-learning can intensify the role of the teacher as a facilitator. It broadens the teachers' perspectives into how to manipulate the e-learning platform; creating 
fun in learning to spell. Besides, Miks \& McIlwaine (2020) reflected the importance of parental support to a child's development. The implication of this study on parents shows that parents play a role in ensuring designated periods of study and ample breaks for their children to be mentally recharged.

\section{Conflicts of Interest}

The authors declare no conflicts of interest regarding the publication of this paper.

\section{References}

Ahmadi, M. R. (2018). The Use of Technology in English Language Learning: A Literature Review. International Journal of Research in English Education, 3, 115-125. https://doi.org/10.29252/ijree.3.2.115

Ahmed, I. A. (2017). Different Types of Spelling Errors Made by Kurdish EFL Learners and Their Potential Causes. International Journal of Kurdish Studies, 3, 93-110. https://doi.org/10.21600/ijoks.334146

Amin, F. (2012). British or American English Lifestyle. The Star. https://www.thestar.com.my/lifestyle/viewpoints/mind-our-english/2012/03/06/britishor-american-english

Bakar, S. F. A., Fauzi, F. H., Yasin, N. F. M., \& Yunus, M. M. (2018). Compound Chunk: Telegram Autobot Quiz to Improve Spelling on Compound Nouns. International Journal of Academic Research in Progressive Education and Development, 8, 48-63.

Botley, S., Faizal, H., \& Dillah, D. (2007). Investigating Spelling Errors in a Malaysian Learner Corpus. Malaysian Journal of ELT Research, 3, 74-93.

Chartrand, R. (2011). Social Networking for Language Learners: Creating Meaningful Output with Web 2.0 Tools. Knowledge Management \& E-Learning: An International Journal, 4, 97-101. https://doi.org/10.34105/j.kmel.2012.04.009

Dheifallah, A., \& Radzuwan, A. R. (2019). Spelling Problems and Causes among Saudi English Language Undergraduates. Arab World English Journal, 10, 178-191. https://doi.org/10.24093/awej/vol10no3.12

Hashim, H. (2018). Application of Technology in the Digital Era Education. International Journal of Research in Counseling and Education, 2, 1-5. https://doi.org/10.24036/002za0002

Kamenetz, A. (2020). What Do Students Need to Recover When School Closes for Months? Education, NPR. https://www.npr.org/2020/04/01/825056995/what-do-students-need-to-recover-when-s chool-closes-for-months

Krashen, S. D. (1985). The Input Hypothesis: Issues and Implications. New York: Longman.

Menelaos, S., \& Chris, P. (2011). Word Spelling Assessment Using ICT: The Effect of Presentation Modality. Themes in Science and Technology, 3, 93-118.

Miks, J., \& McIlwaine, J. (2020). Keeping the World's Children Learning through COVID-19. UNICEF.

https://www.unicef.org/coronavirus/keeping-worlds-children-learning-through-COVI $\underline{\mathrm{D}-19}$

Ministry of Education Malaysia (2018). Kurikulum Standard Sekolah Rendah. Bahasa Inggeris Sekolah Kebangsaan. In Dokumen Standard Kurikulum dan Pentaksiran Tahun 
4. Putrajaya: Bahagian Pembangunan Kurikulum.

Mohamad, M., Arif, F. K. M., \& Noor, N. M. (2020). Online Game-Based Formative Assessment: Distant Learners Post-Graduate Students' Positive Perceptions towards Quizizz. International Journal of Scientific \& Technology Research, 9, 1438-1444.

Mohamad, M., Ghazali, N., \& Hashim, H. (2018). Secondary School Students' Perceptions on the Use of Google+ towards Improving ESL Writing Skills. International Journal of Emerging Technologies in Learning, 13, 224-238. https://doi.org/10.3991/ijet.v13i09.8479

Perveen, U., \& Akram, F. (2014). A Comparative Study to Know the Causes of Spelling Errors Committed by Learners of English at Elementary Level in District Kasur and Lahore in Pakistan. European Academic Research, 2, 2601-2622.

Peter, T., Jean, H., \& Proquest Firm (2013). International English: A Guide to the Varieties of Standard English (5th ed.). London: Taylor and Francis.

Qing, C., Ming, Z., \& Mu, L. (2007). Improving Query Spelling Correction Using Web Search Results. In Proceedings of the 2007 Joint Conference on Empirical Methods in Natural Language Processing and Computational Natural Language Learning (pp. 181-189).

Rafiq, K. R. M., Pazilah, F. N., Goh, Y. T., Yunus, M. M., \& Hashim, H. (2020). Game on! Development and Evaluation of Computer Games for ESL Classroom. International Journal of Scientific \& Technology Research, 9, 1976-1980.

Rahman, D. (2020). A Reckoning for Online Learning in Times of Crisis. Opinion, The Star.

https://www.thestar.com.my/opinion/columnists/whats-your-status/2020/03/24/a-reck oning-for-online-learning-in-times-of-crisis

Rana, S., Ardichvili, A., \& Polesello, D. (2016). Promoting Self-Directed Learning in a Learning Organization: Tools and Practices. European Journal of Training and Development, 40, 470-489. https://doi.org/10.1108/EJTD-10-2015-0076

Samuddin, K. M., \& Krish, P. (2018). English Ortographic Depth among Malay Learners at a Primary School. 3L: Language, Linguistics, Literature, 24, 56-68. https://doi.org/10.17576/3L-2018-2401-05

Shahroom, A. A., \& Hussin, N. (2018). Industrial Revolution 4.0 and Education. International Journal of Academic Research in Business and Social Sciences, 8, 314-319. https://doi.org/10.6007/IJARBSS/v8-i9/4593

Sumreet, K. R., \& Charanjiv, S. S. (2014). Study of Spell-Checking Techniques and Available Spell Checkers in Regional Languages: A Survey. International Journal for Technological Research in Engineering, 2, 148-151.

Thirusanku, J., \& Yunus, M. M. (2014). Status of English in Malaysia. Asian Social Science, 10, 254-260. https://doi.org/10.5539/ass.v10n14p254

Treiman, R., Kessler, B., \& Caravolas, M. (2019). What Methods of Scoring Young Children's Spelling Best Predict Later Spelling Performance. Journal of Research in Reading, 42, 80-96. https://doi.org/10.1111/1467-9817.12241

Verheijen, L. (2013). The Effects of Text Messaging and Instant Messaging on Literacy. English Studies, 94, 582-602. https://doi.org/10.1080/0013838X.2013.795737

Westwood, P. (2014). Teaching Spelling: Exploring Common Sense Strategies and Best Practices. New York: Routledge. https://doi.org/10.4324/9781315815909

Yeung, S. S., \& Qiao, S. (2019). Developmental Trends and Precursors of English Spelling in Chinese Children Who Learn English as a Second Language: Comparisons between Average and At-Risk Spellers. Research in Developmental Disabilities, 93, Article ID: 
103456. https://doi.org/10.1016/j.ridd.2019.103456

Yunus, M. M., Lau, E. Y. Y., Mohd Khair, A. H., \& Yusof, N. M. (2020). Acquisition of Vocabulary in Primary Schools via GoPic with QR Code. International Journal of English Language and Literature Studies, 9, 121-131. https://doi.org/10.18488/journal.23.2020.93.121.131

Yunus, M. M., Nordin, N., Salehi, H., Embi, M. A., \& Salehi, Z. (2014). Future of ICT as a Pedagogical Tool in ESL Teaching and Learning. Research Journal of Applied Sciences, Engineering and Technology, 7, 764-770. https://doi.org/10.19026/rjaset.7.314

Yunus, M. M., Salehi, H., \& John, D. S. A. (2013). Using Visual Aids as a Motivational Tool in Enhancing Students' Interest in Reading Literary Texts. In Recent Advances in Educational Technologies (pp. 114-117). 